\title{
Implementation of UI GreenMetric at Diponegoro University in order to Environmental Sustainability Efforts
}

\author{
Effine Lourrinx ${ }^{1 *}$, Hadiyanto ${ }^{1}$, and Mochamad Arief Budihardjo ${ }^{2}$ \\ ${ }^{1}$ Master Program of Environmental Science, School of Postgraduate Studies, Diponegoro University, Semarang - Indonesia \\ ${ }^{2}$ Department of Environmental Engineering, Faculty of Engineering, Diponegoro University, Semarang - Indonesia
}

\begin{abstract}
Green campus is a concept, which integrates environmental science into policy, management and activities of the college. Green campus is also the implementation of the integration of environmental science in all aspects of management and sustainable development practices. Therefore, the standards for referral and encouragement to management in developing a green campus program are needed, one of which is UI GreenMetric. The purpose of this study are to determine how the program of UI GreenMetric is implemented at Diponegoro University and to provide recommendations in the category or indicator that has not been fulfilled. Optimizing the implementation of UI GreenMetric can be used as a further reference in the development of green campus concept in Indonesia. This study uses data in the form of a literature study of standards and guidelines used by UI GreenMetric which are considered in accordance with the strategy of increasing effectiveness in implementing green campus. The results showed the value obtained by Diponegoro University in the UI GreenMetric World University Rankings standards.
\end{abstract}

Keywords: sustainability; green campus; UI GreenMetric.

\section{Introduction}

Environmental dimension of development or environmental concept known as sustainable development have been agreed by most of the countries in the world, including Indonesia, as concepts, strategies and models that are expected to keep the environment function [1].

In this context, the participation of independent organizations with high public credibility as the university is required. Given that the university has a role to create the knowledge, integrating sustainable education and research programs, and promoting environmental issues to the public [3]. University is responsible to increasing the values, awareness, knowledge, and skills in sustainable development [10]. Universities are expected to make concrete efforts in realization green campus' label through programs and campus culture.

Green campus is the system of education, research, community dediaction, and a eco-friendly location and should have a positive impact on the environment, economic and social [6].

Therefore, the standards for referral and encouragement to management in developing a green campus program are needed, one of which is UI GreenMetric. UI GreenMetric is a standard made by the University of Indonesia, which is the first university ranking system in the world that bases its main assessment is the college's commitment in environmental management of campus.
Diponegoro University as an entity of higher education in Indonesia has grown since its inception to the present. In the Strategic Plan of Diponegoro University by the 2015-2019, Diponegoro University has targets and programs that to increase opportunity for university ranking at national level, Asia and the world and ranked by the UI GreenMetric in case of environmental empowerment.

The purpose of this study are to determine how the program of UI GreenMetric is implemented at Diponegoro University and to provide recommendations in the category or indicator that has not been fulfilled.

\section{Literature Review}

\subsection{Sustainability in higher education}

Sustainable development is one of the biggest challenges in recent years. Several universities have begun to find the content of this concept and how to implement it in policy, organization, and activities in universities [4].

The sustainability concept contains at least two dimensions First, the time dimension because sustainability concerns what will happen in the future. The second is the dimension of the interaction between economic system and the system of natural resources and the environment [2].

Due to the multi-dimensional and multi-interpretation in describing the concept of sustainability, the experts temporarily adopt the understanding that has been agreed

* Corresponding author: effineTL@gmail.com 
by Brundtland commission which states "Sustainable development is development that meets the needs of the present generation without compromising the ability of future generations to meet their own needs." [14].

\subsection{Green campus}

Green campus is the system of education, research, community dedication, and a eco-friendly location and should have a positive impact on the environment, economic and social. Green campus has an intellectual capacity and resources in integrating science and environmental values into its mission and programs. Green campus must also be an example of the implementation of integration of environmental science in all aspects of management and sustainable development best practices [6].

Green campus concepts consists of green buildings, energy, water, food, transportation, purchasing, waste and sustainable landscaping [13].

The contribution of the university to environmental degradation as a result of their own operational activities has prompted the emergence of the concept of the green campus [11]. Green campus development will build a solution to lay equal emphasis on the soft power of green environment protection and the fixed low-carbon target, and will be full life cycle assessment-oriented [7].

According to the refference [8], if the concept of a green campus is developed with the knowledge, flexibility, dynamism, openness and implementation through an adaptive process, they will be more successful than the initiatives inheriting the rigidity of university structure.

\subsection{UI GreenMetric}

UI GreenMetric is a world university ranking system that was launched by University of Indonesia in 2010 for universities to assess and compare campus sustainability efforts. UI GreenMetric is allowed to global participation, accessible to HEIs in both developed and developing countries and should contribute to academic discourse on sustainability in education and the greening of campuses. It must also encourage university-led social change related to sustainability goals [5].

UI GreenMetric World University Ranking was created as a tool for universities to answer the sustainability problems currently faced by the world. Universities can work together to reduce the consequences of environmental problems and UI GreenMetric is a non-profit institution so that all universities can participate without being charged [12].

UI GreenMetric themes initiated in 2018 is "Universities, Impacts and Sustainable Development Goals (SDGs)", with an emphasis on the efforts of university and partners on sustainability issues to see the further partnership improvement in the campus sustainability [12].

\section{Methods}

Refers to the type of research conducted that research aims to determine how the program of UI GreenMetric is implemented at Diponegoro University and to provide recommendations in the category or indicator that has not been fulfilled

This study uses a qualitative research method with rationalistic approach. Rationalistic qualitative research methods is started from a holistic approach in the form of grand concepts, researched on the specific object, and reinstated the results with the grand concepts [9].

Analysis of the concept of a green campus guided by the parameters of the UI GreenMetric 2019 Guideline and UI GreenMetric as grand concepts. There are six categories in the UI GreenMetric standard i.e. Setting and Infrastructure, Energy and Climate Change, Waste, Water, Transportation and Research and Education.

Process of collecting and analyzing data use a qualitative approach to interviewing university manager as informants, observations and field measurements. Data collection is conducted at 13 faculties in the Diponegoro University. List of faculties can be seen in Table 1.

Table 1. List of faculties in Diponegoro University.

\begin{tabular}{|c|c|}
\hline No & Faculties \\
\hline 1 & Economics and Business \\
\hline 2 & Law \\
\hline 3 & Cocial Science and Political Science \\
\hline 4 & Medicine \\
\hline 5 & Public health \\
\hline 6 & Animal and Agricultural Science \\
\hline 7 & Fisheries and Marine Sciences \\
\hline 8 & Psychology \\
\hline 9 & Science and Mathematics \\
\hline 10 & Engineering \\
\hline 11 & School of Postgraduate Studies \\
\hline 12 & Vocational School \\
\hline 13 & \\
\hline
\end{tabular}

From interviews and observations and then combined with the 2018 Guideline GreenMetric UI parameters to obtain the theme of the discussion of the study. The weight of each category of assessment in UI GreenMetric can be seen in Table 2.

Table 2. The weight of each category of assessment GreenMetric UI.

\begin{tabular}{|c|l|l|}
\hline No & \multicolumn{1}{|c|}{ Categories } & $\begin{array}{c}\text { Weighting } \\
(\mathbf{\%})\end{array}$ \\
\hline 1 & Setting and Infrastructure & 15 \\
\hline 2 & Energy and Climate Change & 21 \\
\hline 3 & Waste & 18 \\
\hline 4 & Water & 10 \\
\hline 5 & Transportation & 18 \\
\hline 6 & Research and Education & 18 \\
\hline & Total & $\mathbf{1 0 0}$ \\
\hline
\end{tabular}


After collecting the results of interviews and observastions, then will obtain the data needed to review how the UI GreenMetric have been implemented and to provide recommendations for mitigation measures to be implemented in order to increase the categories or indicators that have not been fulfilled.

\section{Discussion}

\subsection{Setting and infrastructure}

Setting and infrastructure of campus will provide an overview of the campus tendency towards a green environment. This indicator will also eventually shows a decent college called green campus or not. The aim is to trigger the participant universities to provide more green open space for greening and maintaining the environment and sustainable energy.

Table 3. Indicators of setting and infrastructure sector.

\begin{tabular}{|c|l|l|}
\hline No & \multicolumn{1}{|c|}{ Indicators } & Score \\
\hline 1 & $\begin{array}{l}\text { Comparison between the green open } \\
\text { space with a total area of campus }\end{array}$ & 300 \\
\hline 2 & $\begin{array}{l}\text { Percentage of Diponegoro } \\
\text { University campus forested area }\end{array}$ & 200 \\
\hline 3 & $\begin{array}{l}\text { Percentage of campus area covered } \\
\text { with plants / gardens (including } \\
\text { lawns, gardens, etc.) }\end{array}$ & 300 \\
\hline 4 & $\begin{array}{l}\text { Percentage of surface area on } \\
\text { campus that can absorb water } \\
\text { (including ground or konblok) }\end{array}$ & 200 \\
\hline 5 & $\begin{array}{l}\text { Total open space divided by the } \\
\text { population of the campus }\end{array}$ & 300 \\
\hline 6 & $\begin{array}{l}\text { Percentage of RKAT to realize a } \\
\text { sustainable campus }\end{array}$ & 200 \\
\hline & Total & $\mathbf{1 5 0 0}$ \\
\hline
\end{tabular}

\subsection{Energy and climate change}

College's attention to the issues of energy use and climate change is an indicator with the highest weight value. In the questionnaire, the determination of several indicators for areas of special concern such as the use of tools of energy saving, implementation of smart building, policy renewable energy use, total energy use, energy conservation programs, elements of green building, climate change adaptation and mitigation, reduction policies of greenhouse gases and the amount of carbon. With these indicators, colleges are expected to intensify efforts for the energy efficiency of their buildings and to be more concerned about the nature and source of energy.

Table 4. Indicators of energy and climate change sector.

\begin{tabular}{|c|l|c|}
\hline No & \multicolumn{1}{|c|}{ Indicators } & Score \\
\hline 1 & $\begin{array}{l}\text { The use of energy efficient } \\
\text { equipment replaces the conventional } \\
\text { devices }\end{array}$ & 200 \\
\hline 2 & Implementation of smart building & 300 \\
\hline
\end{tabular}

\begin{tabular}{|c|l|l|}
\hline No & \multicolumn{1}{|c|}{ Indicators } & Score \\
\hline 3 & $\begin{array}{l}\text { program } \\
\text { The amount of renewable energy } \\
\text { sources }\end{array}$ & 300 \\
\hline 4 & $\begin{array}{l}\text { Total electricity consumption } \\
\text { divided by the population of the } \\
\text { campus }\end{array}$ & 300 \\
\hline 5 & $\begin{array}{l}\text { The ratio between the production of } \\
\text { renewable energy to the total energy } \\
\text { use (years) }\end{array}$ & 200 \\
\hline 6 & \begin{tabular}{l} 
Application of Green Building \\
\hline 7
\end{tabular} & $\begin{array}{l}\text { Programs to reduce greenhouse gas } \\
\text { emissions }\end{array}$ \\
\hline 8 & $\begin{array}{l}\text { The ratio of total carbon footprint } \\
\text { divided by the population of the } \\
\text { campus }\end{array}$ & 300 \\
\hline & Total & $\mathbf{2 1 0 0}$ \\
\hline
\end{tabular}

\subsection{Waste}

Activities of processing and recycling of waste is a major factor in creating a sustainable environment. The activities of university staff and students in the campus will produce a lot of waste; therefore, some recycling programs and waste management should be one of the concerns of the university, such as the recycling program, recycling of toxic waste, organic waste processing, waste treatment inorganic, disposal of sewage, policies to reduce the use of paper and plastic in campus.

Table 5. Indicators of waste sector.

\begin{tabular}{|c|l|l|}
\hline No & \multicolumn{1}{|c|}{ Indicators } & Score \\
\hline 1 & Waste recycling program & 300 \\
\hline 2 & $\begin{array}{l}\text { Programs to reduce the use of paper } \\
\text { and plastic }\end{array}$ & 300 \\
\hline 3 & $\begin{array}{l}\text { The processing of organic waste } \\
\text { (garbage, waste vegetables and } \\
\text { herbs) }\end{array}$ & 300 \\
\hline 5 & $\begin{array}{l}\text { Treatment of inorganic waste } \\
\text { (garbage, waste paper, plastic, metal, } \\
\text { etc.) }\end{array}$ & 300 \\
\hline 5 & $\begin{array}{l}\text { Handling of the toxic waste at the } \\
\text { campus (whether the toxic waste is } \\
\text { handled separately, for example by } \\
\text { grouping and collected) }\end{array}$ & 300 \\
\hline 6 & $\begin{array}{l}\text { Liquid waste disposal (main method } \\
\text { of waste treatment) }\end{array}$ & 300 \\
\hline & Total & $\mathbf{1 8 0 0}$ \\
\hline
\end{tabular}

\subsection{Water}

Water use on campus is another important indicator in the UI GreenMetric standard. The aim is to encourage campuses to reduce water use, improve conservation programs, and protect habitat. Water conservation programs, water recycling programs, water use efficiency programs, and the use of treated water are among the criteria. 
Table 6. Indicators of water sector.

\begin{tabular}{|c|l|l|}
\hline No & \multicolumn{1}{|c|}{ Indicators } & Score \\
\hline 1 & $\begin{array}{l}\text { Implementation of water } \\
\text { conservation programs on campus }\end{array}$ & 300 \\
\hline 2 & $\begin{array}{l}\text { Implementation of the utilization of } \\
\text { recycled water program }\end{array}$ & 300 \\
\hline 3 & $\begin{array}{l}\text { The use of water-saving equipment } \\
\text { The ratio between the use of water- } \\
\text { based pipe (PAM) with total water } \\
\text { use }\end{array}$ & 200 \\
\hline & Total & $\mathbf{1 0 0 0}$ \\
\hline
\end{tabular}

\subsection{Transportation}

The transportation system holds an important role on carbon emissions and pollution levels on campus. Transportation policy in order to limit the number of vehicles, the use of campus bus and bicycle use will encourage a more healthy environment. Pedestrian policy will encourage students and employees to walk around the campus, and avoid the use of private vehicles. The use of environmentally friendly public transport will reduce carbon pollution in the campus.

Table 7. Indicators of transportation sector

\begin{tabular}{|c|c|c|}
\hline No & Indicators & Score \\
\hline 1 & $\begin{array}{l}\text { The ratio of the number of vehicles } \\
\text { divided by the population of the } \\
\text { campus }\end{array}$ & 200 \\
\hline 2 & Campus shuttle operational mode & 300 \\
\hline 3 & $\begin{array}{l}\text { Policies regarding emission-free } \\
\text { vehicles on campus }\end{array}$ & 200 \\
\hline 4 & $\begin{array}{l}\text { The ratio of emission-free vehicles } \\
\text { divided by the population of the } \\
\text { campus }\end{array}$ & 200 \\
\hline 5 & $\begin{array}{l}\text { The ratio of total parking area to the } \\
\text { total area of the campus }\end{array}$ & 200 \\
\hline 6 & $\begin{array}{l}\text { The percentage reduction in the } \\
\text { parking area for private vehicles in } \\
\text { the last } 3 \text { years }\end{array}$ & 200 \\
\hline 7 & $\begin{array}{l}\text { Initiative limiting the number of } \\
\text { private vehicles entering the campus } \\
\text { area }\end{array}$ & 200 \\
\hline \multirow[t]{2}{*}{8} & Support for the pedestrians & 300 \\
\hline & Total & 1800 \\
\hline
\end{tabular}

\subsection{Research and education}

Research and education category has an important role in the process of sustainable development and environmentally empowerement. Environmental education creates a learning process in shaping the personality of learners are aware of the environment, understand the concept of environmentally friendly, as well as master cultured eco-friendly lifestyle.
Table 8. Indicators of research and education sector.

\begin{tabular}{|c|l|l|}
\hline No & \multicolumn{1}{|c|}{ Indicators } & Score \\
\hline 1 & $\begin{array}{l}\text { The ratio of subjects related to the } \\
\text { overall value of environmental } \\
\text { sustainability courses }\end{array}$ & 300 \\
\hline 2 & $\begin{array}{l}\text { The ratio of research funding which } \\
\text { dedicated to ongoing research } \\
\text { environment over the entire campus } \\
\text { research funding }\end{array}$ & 300 \\
\hline 3 & $\begin{array}{l}\text { Number of published scientific } \\
\text { publications on environmental } \\
\text { sustainability (the average number of } \\
\text { issued every year for 3 years) }\end{array}$ & 300 \\
\hline 4 & $\begin{array}{l}\text { Number of campus activities/ events } \\
\text { related to environmental } \\
\text { sustainability (conferences etc.) } \\
\text { (average per year over the last 3 } \\
\text { years) }\end{array}$ & 300 \\
\hline 5 & $\begin{array}{l}\text { The number of student organizations } \\
\text { related to environmental } \\
\text { sustainability }\end{array}$ & 300 \\
\hline 6 & $\begin{array}{l}\text { Availability page on environmental } \\
\text { sustainability }\end{array}$ & 200 \\
\hline 7 & $\begin{array}{l}\text { Availability of reports on } \\
\text { environmental sustainability }\end{array}$ & 100 \\
\hline Total 1800 \\
\hline
\end{tabular}

\section{Conclusion}

UI GreenMetric in 2019 focused on efforts of universities that related to the issue of sustainability to see further about partnerships improvement in the university campus sustainability. Categories on the assessment of UI GreenMetric that must be met which include Setting and Infrastructure, Energy and Climate Change, Waste, Water, Transportation and Research and Education.

Given this research is expected to realize the objectives and programs of Diponegoro University as an entity of higher education to achieve environmental ranked by UI GreenMetric.

\section{References}

1. S.P. Hadi, Dimensi Lingkungan Perencanaan Pembangunan, UGM Press Yogyakarta (2005)

2. G. Heal, Valuing the Future : Economic Theory and Sustainability, Columbia University Press, New York (1998)

3. H.N. Larsen, J. Pettersen, C. Solli, E.G. Hertwich, Journal of Cleaner Production 48, 39-47 (2013)

4. H.V. Weenen, Intl. Journal of Sustainability in Higher Edu. 1(1), 20-34 (2000)

5. H. Zain, N. Zalina bt Mahmood, Z.F. Mohamad, BIMP Journal of Regional Development 1, 1 (2015) 
6. H. Hudaini, Green Campus Vs Global Warming and Its Degradation $7^{\text {th }}$ series, Green Motivation, UEA, (2011)

7. H. Tan, S. Chen, Q. Shi, L. Wang, Journal of Cleaner Production 64 (2014)

8. L. Sharp, International Journal of Sustainability in Higher Education 3(2), 128-145 (2002)

9. N. Muhadjir, Metode Penelitian Kulitatif. 4th edition, PT. Bayu Indra Grafika, Yogyakarta (2000)

10. A.D. Cortese, The critical role of higher education in creating a sustainable future, Plan. High. Educ. 31, 15-22 (2003)

11. S. Jain, P. Pant, International Journal of Sustainability in Higher Education 11(3), 236-249 (2010)

12. Universitas Indonesia, Petunjuk UI Greenmetric World University Ranking 2018, Universitas Indonesia, Depok (2018)

13. W. Calder, J. Dautremont-Smith, Higher education: more and more laboratories for inventing a sustainable future, In J. Dernbach, (Ed.) "Agenda for a Sustainable America". Washington, DC: Environmental Law Institute, 93-107 (2009)

14. World Commission on Environment and Development (WCED), Our Common Future, Oxford University Press: New York (1987) 